\title{
MEMORIAL SOBRE A TRAJETÓRIA ESCOLAR BÁSICA DE SIMONE NUNES SANCHES
}

\author{
Simone Nunes Sanches ${ }^{1}$
}

Resumo: O presente texto trata do memorial sobre a trajetória escolar de Simone Nunes Sanches, ex-integrante do Programa Conexões de Saberes. Tem como objetivo apresentar os passos percorridos desde o início da educação básica até a entrada à UFPA e quais os principais entraves de estudantes das comunidades populares adentrarem o ensino superior público. A memória foi usada como principal referência para construção do material. Em seus resultados, apresenta os esforços individual e coletivo para que de fato a educação seja uma questão de direito e não de privilégio de poucos.

Nasci no Rio Arrozal, na tarde de 29 de Dezembro de 1987, o parto foi muito complicado e dorido para minha mãe, pois na época só contava com a parteira uma vez que a localidade é muito longe da cidade de Breves, na qual vim morar quando tinha três anos de idade.

No início foi bem difícil, no lugar em que morávamos não tinha energia elétrica e água encanada. Nós éramos dependentes dos carros pipas e do igarapé que fica próximo de minha casa, claro que ainda não era poluído como é hoje. Tomávamos banho, lavávamos roupas e louças tudo lá. Enquanto a água dos carros Pipas servia para bebemos e cozer os alimentos. Nossa casa era praticamente no meio do mato, a "rua" era mais um estreito caminho feito de pedaços de madeira. Meu pai logo conseguiu um emprego em uma madeireira, pois analfabeto, só sabia mexer com a fabricação de madeiras, que na época, estava na sua intensa produção, gerando desenvolvimento e principalmente empregos para quem acabara de chegar à cidade. Nesse período era intenso o êxodo rural, a fim de uma vida melhor e educação para os seus filhos. Na realidade isso acontece até hoje provocando um crescimento desordenado a cidade, que por sua vez oferece o mínimo de saneamento básico para a sua população.

Com cinco anos comecei a estudar no pré-escolar Carneirinho Manhoso, me lembro que minha mãe me acordava cedo, me dava banho, me vestia e amarrava meus cabelos. Então eu pegava meu caderno e eu ia embora, nunca chorei na escola, minha prima Lidiane sempre foi minha grande amiga, começamos a ler juntas, fomos as primeiras da turma, a ganhar as antigas cartilhas, éramos consideradas as mais inteligentes.

\footnotetext{
1 Acadêmica* de Licenciatura Plena em Letras da Universidade Federal do Pará, e-mail: simoneconexoes@ hotmail.com

* atualizado pela última vez em 2008.
}

Revista PET Interdisciplinar e Programa Conexões /UFPA On-line. Ed. Especial - 2017, BELÉM/ PA - ISSN 2447-097X 
Quando aprendi a ler, quis ensinar o meu irmão, que tinha começado a estudar, era engraçado, pois a energia elétrica não era permanente, geralmente tinha energia só durante o dia, eu pegava uma lamparina e meu irmão Sival, e íamos para um canto da sala com uma cartinha, e tentava ensiná-lo a ler como minha professora do pré-escolar, ás vezes ele não queria, mas eu o obrigava a estudar comigo.

Aos sete anos, fui para a Escola Rossilda Ferreira, onde estudei até a quarta série. No meu primeiro ano nessa escola, foi demais, aprendia cada vez mais, principalmente com a professora Odete que era muito divertida, mas por outro lado não estava tão alegre porque minha prima estudava em outro horário, me lembro que no meio do ano, nossa professora adoeceu e tiveram que separar a turma para outras duas classes. Recordo-me que não queria ir para a turma da professora Isa, pois ela era considerada a mestra mais rígida da escola. Em seguida, na época, passei para a $1^{\circ}$ forte, tivemos que trocar de escola no meio do ano letivo, para reformas, era difícil porque o outro colégio ficava muito longe e o horário que nós estudávamos correspondia ao chamado intermediário*. Chegando na $2^{\mathrm{a}}$ série eu descobri o meu ponto fraco: a matemática, mesmo assim eu adorava ir para escola. Eu usava uma bolsa que se parecia com uma pasta de executiva me sentia muito importante, ainda mais quando meu pai falava: "Lá vem minha futura doutora". Eu e minha prima tínhamos muita dificuldade de divisão, fomos obrigadas a ter aulas extras de matemática e com a professora Isa, que sempre exigiu algo a mais de todos os seus alunos, depois vim reconhecer a excelente professora que é, e como poucos ela ama a profissão que exerce. Prosseguindo fiz $3^{\mathrm{a}}$ série, na ocasião nós estávamos construindo uma nova casa, minha irmã casula acabara de nascer. Continuando minha vida na escola, já na $4^{\circ}$ série, aprendi muito, inclusive a suportar a dor de ter perdido a minha tia, mãe de Lidiane, sofremos muito.

Apesar de tudo a vida continuava, e dentro do possível estava melhor, meu pai ganhava um pouquinho mais e conseqüentemente tudo melhorava. Nós, primas, ainda éramos muito brincalhonas, fazíamos diversas casinhas no quintal, brincávamos muito de bonecas e na rua, eram brincadeiras como: taco, macaca, elástico e garrafão. Era divertido.

$\mathrm{Na} 5^{a}$ série, já em outro colégio, na Odízia Corrêa Farias, sonhos novos e amigos diferentes, foi emocionante, lá tinha quadra adorava brincar de futsal, mas sempre fui maior perna de pau, foi lá também que me apaixonei pela primeira vez por um garoto sequelo, mas minha prima não gostou da idéia, pois me achava muito nova para namorar. Para cursar a $6^{\circ}$ série, mudei de horário, fui estudar pela parte da manhã, foi aí que eu cometi as maiores burradas da minha vida, brigava em casa ia mal na escola, tinha amizades que só me levavam

Revista PET Interdisciplinar e Programa Conexões /UFPA On-line. Ed. Especial - 2017, BELÉM/ PA - ISSN 2447-097X 
para o mau caminho, foi preciso muitos conselhos e castigos para que eu pudesse voltar ao bom caminho. Lembro-me que uma das melhores soluções foi meu encontro com Deus depois que o achei jamais quis perdê-lo. A $7^{\mathrm{a}}$ serie foi tudo de bom me destaquei em matemática só tirava dez, fui líder da sala passei com vantagem para a $8^{\circ}$ serie, que foi tudo de bom, pois era nosso último ano no colégio, além de estudar muito também nos divertíamos e para fechar o ensino fundamental com chave de ouro fizemos uma festa, em comemoração a mais uma etapa escolar conseguida.

Enfim, cheguei ao ensino médio, na escola estadual Maria C. Paes, era muito bom estar no ensino médio, pois não parava de pensa no PSS, Processo Seletivo Seriado da UFPA, que consistia na realização de uma prova a cada ano concluído do ensino médio. A partir do primeiro ano do Ensino Médio, a aprovação no vestibular passou a ser o meu maior desafio. Foi assim que aconteceu a cada final de ano prestava a prova correspondente ao exame seletivo da Universidade Federal do Pará, foi nesse período que sentir a tamanha deficiência da escola pública, porque disputar com um aluno da capital que além de ter a classe normal tem mais a ajuda de cursinho, sem contar com a equipe de profissionais bem capacitados que se dispõe a ajudá-lo. Para o vestibulando do interior tudo é mais difícil. Digo isso porque conheço a realidade marajoara, sou um exemplo de quanto é difícil se manter na escola. Principalmente quando se trata da nossa cidade, Breves, que infelizmente é tão famosa pela prostituição infantil. Agora então, com o desemprego em massa tudo se tornou mais difícil. Nossa região é movida pelo extrativismo de madeira, com a preservação da floresta, as empresas madeireiras são impedias de funcionar, deixando nossa cidade em caos, pois não foi feito projeto sustentável para que o brevense, com a proibição da derrubada de árvore, não morresse de fome. Eu entendo que a extração de árvores e o processo industrial que ela sofre sejam extremamente prejudiciais à camada de ozônio, o ecossistema e conseqüentemente a nós, mas a culpa não é somente nossa, marajoaras, de que um planeta está se tornado uma caldeira, pois todos poluíram muito, principalmente os países e cidades mais desenvolvidas, à custa, óbvio, dos trabalhadores primários, agora querem nos sacrificar para salvarem a eles próprios, mais em vez de nossos governantes nos defenderem não, preferem abaixar a cabeça para os "salvadores" do planeta. È injusto, nós queremos viver, pois infelizmente não sabemos sobreviver igual aos índios, já fomos contaminados pelo capitalismo selvagem.

Quando cursávamos o $3^{\circ}$ ano consegui uma bolsa em um cursinho, infelizmente o cursinho no meio do ano fracassou tivemos que passar para outro, para minha sorte consegui manter a bolsa foi aí que eu encontrei uma pessoa muito especial que hoje é meu namorado, 
nós nos apoiamos muito nessa etapa final do vestibular, pois a pressão é grande, mas mesmo assim, me candidatei a ingressar na UEPA (Universidade Estadual do Pará), e também estava apta para realizar a última fase do vestibular da UFPA (Universidade Federal do Pará), na universidade do Estado estava concorrendo para uma vaga no curso de Licenciatura Plena em Matemática e na Federal estava prestando para o curso de Licenciatura Plena em Letras. Bem, no do Estado não conseguir passar, mas na Federal corri para o abraço.

No dia do resultado fiquei muito aflita, esperava o listão pela rádio, minha mãe estava ao meu lado, chorava muito quando saiu o meu nome dei um grito, agradeci tanto a Deus, fui pra rua junto com minha prima que também passou em História e meu namorado que passou em Pedagogia. Essa felicidade só foi possível graças a minha família que sempre me deu muito apoio para eu estudar encontrei sim muitas dificuldades, ainda é triste quando olho para trás e vejo meus antigos colegas que não conseguiram concluir o Ensino Fundamental ou o Médio, pessoas que não tiveram a mesma oportunidade de entrar para uma universidade, estudantes que muitas vezes foram obrigados a deixar de estudar para trabalhar ou até mesmo para criar seus filhos, de uma gravidez que não foi planejada. Mas é por eles que escrevo o meu Memorial dando, ênfase nas dificuldades que a nossa classe tem para ter o mínimo de Educação. Essa mesma que se tornou um funil em nosso país.

Estudar é uma trajetória estreita, demorada e cara para nós e nossos pais. Pois, antes de chegar aqui foram muitos cadernos e apostilas que meu pai nunca se negou a comprar, mas só depois de passar por muitas barreiras que podemos sentir a satisfação de ter chegado onde se almeja. Hoje faço Letras não vou dizer que é o curso de meu sonho, mas passou a fazer parte da minha realidade. Eu lutei tanto para chegar onde estou, por isso, jamais vou desvalorizar o que eu conseguir; espero sim, um dia poder passar em Educação Física, que é o curso dos meus sonhos, mas sem deixar Letras que hoje é a minha paixão. Por fim, estar em uma universidade é entrar em um universo de conhecimentos riquíssimos, tanto para o profissional quanto para a vida que infelizmente é possível para poucos.

Revista PET Interdisciplinar e Programa Conexões /UFPA On-line. Ed. Especial - 2017, BELÉM/ PA - ISSN 2447-097X 